\title{
Teaching Professionalization of the Current Need Physician
}

Claribel Plain Pazos ${ }^{1 *}$, Carmen Rosa Carmona Pentón ${ }^{1}$, Elsa Núñez Escobar ${ }^{2}$, Anisbel Pérez de Alejo Plain ${ }^{3}$, Lizette Alfonso Garcia ${ }^{4}$, Nereyda Caraballo Moya ${ }^{5}$, Yaquelyn Martínez Chávez

${ }^{I}$ Specialist of II Degree in Comprehensive General Medicine, Assistant Professor, Faculty of Medical Sciences of Sagua la Grande, Villa Clara, Cuba.

${ }^{2}$ Specialist of I Degree in Comprehensive General Medicine, Assistant Professor, Faculty of Medical Sciences of Sagua la Grande, Villa Clara, Cuba

${ }^{3} 3$ rdYear Student of Medicine, Medical Faculty of Medical Sciences of Sagua la Grande, Villa Clara, Cuba

${ }^{4}$ Specialist of I Degree in Psychiatry, Assistant Professor, Teaching General Teaching Hospital "Mártires del 9 de Abril", Sagua la Grande, Villa Clara, Cuba

${ }^{5}$ Specialist of I Degree in Comprehensive General Medicine, Assistant Professor, Faculty of Medical Sciences of Sagua la Grande, Villa Clara, Cuba

${ }^{6}$ Specialist of I Degree in Comprehensive General Medicine and Pharmacology, Assistant Professor, Faculty of Medical Sciences of Sagua la Grande, Villa Clara, Cuba

*Corresponding Author: Claribel Plain Pazos, Specialist of II Degree in Comprehensive General Medicine, Assistant Professor, Faculty of Medical Sciences of Sagua la Grande, Villa Clara, Cuba.

\section{OPINION ARTICLE}

Human resources training is a priority for the National Health System in Cuba. But it is not enough to train human resources, the important thing is to train quality human resources. Education, facing the many challenges that the future imposes, has an essential function in the continuous and dynamic development of the person, essential for it to reach its potential and conquer its self-realization, through competencies that allow it to deploy personal capacities to better understand oneself, understand others and participate, consequently, in social life, and thus be part of a prosperous reality. 1,2

Medical education is also exposed to challenges today, it has been impacted by different transformations, including the focus of competencies in the academic field and this constitutes a growing trend worldwide and these challenges will not depend solely on reformulation of curricula or institutional changes, teachers have a primary role in them. 3 Medical education does not lay its foundations only in the subject of teaching, but also in how to impart it, it is not enough that the student is a passive recipient of knowledge, but that intervene personally in the creation of their own knowledge, for which the professional competence of the teacher in their function as a guide of the self-management of knowledge by the student is very necessary.

The modern era of medicine has brought incredible advances in science and technology designed to improve the health care of patients and the general population. At the same time, these advances have caused a social impact on patients, doctors, medicine, health care and medical education.4,5 In addition to these advances in medicine and science, the medical professionalism of the doctor must go, which is in charge of promoting the learning of his students.

Studies carried out by several authors indicate that there is no identity of the doctor as a teacher, so the topic of teacher professionalization is relevant and is a guideline for research. Not knowing the pedagogical aspects involved in the teaching profession, doctors look for elements such as roles, profiles and identity as a way of approaching the subject. Also in the research on the roles of the professor of Medicine reaffirms the lack of an identity towards the educational field. This shows that there is a need to professionalize teaching in the medical area since when the doctor exercises teaching in front of the students, he does not stop acting as such, that is, he acts as a doctor and not as a teacher.6 
Studies conducted with medical professors reveal that teaching is considered a secondary activity to the medical profession and that the teaching career is not considered a profession.7 However, the medical teacher, as a component of the teaching-learning process, becomes basic piece and its participation acquires active and significant quality as a facilitator of learning, helping at all times to the integral formation of the student. 8

Although it is a generalized criterion of doctors, to think that teaching professionalism is not essential for teaching, that it is enough only with their own knowledge of the medical profession, it has been shown that this statement is not true. Recent studies indicate that assuming that the doctor, because of his quality as such, is qualified to teach, and therefore, that his students learn, is part of the past. The challenge is to go further; It is imperative to have the implementation of properly structured programs, based on the needs assessment within each school and with a study of its impact. 8

In Cuba, the Ministry of Higher Education has established three main teaching categories: assistant professor, assistant professor and teacher. There is also the transitory instructor category, which are established in Ministerial Resolution Number 85/2016: 9 "Regulations for the Application of Teaching Categories of Higher Education". It is essential for the transit through these categories to maintain a satisfactory job as a teacher, as well as to demonstrate knowledge about foreign language and social problems of science, in addition to staying active in research, development and technological innovation. These categories are valid for all higher education, both medical and non-medical.

The profile of the graduate of the medical career in Cuba, in its role of comprehensive medical care, is not only aimed at the healing of the sick but also at their work of promotion, prevention and rehabilitation. The work of the teacher must be aimed at the integral formation of this future health professional, so it is essential to prepare to educate from the instruction, from the content of the subjects, in all scenarios, with the relevance and effectiveness that requires the successful development of the functions corresponding to their teaching category, to contribute to the integral formation of the students.
Only a competent teacher is able to create skills in their students.

It must be the political will of the States of each country to work in order to achieve these objectives.

\section{REFERENCES}

[1] Álvarez Bobadilla GM. Profesionalización de la educación en el área dela medicina y anestesiología. Revista Mexicana de Anestesiología 2018; 41(4): 235-236. Available in: https://www.medigraphic. Com /pdfs/ rma/cma-2018/cma184a.pdf

[2] Estévez Pichs MA, Rojas Valladares AL. Gestión de proyectos de vinculación con la sociedad. Un tema preciso en la profesionalización del docente. Conrado 2018; 14(64), 139-145. Available in:http://scielo. sld.cu/scielo.php?pid=S1990-86442018000400 $139 \&$ script= sci_arttex $t \& t \operatorname{lng}=$ enhttp://scielo. sld.cu/scielo. php?pid=S1990-86442018000 40 0139\&script $=$ sci_arttext\&tlng=en

[3] Vidal Borras E, Guerra RomanJY,Marrero Hidalgo MM.Desempeño docente de los especialistas de medicina general integral en la Facultad Ciencias Médicas Miguel Enríquez.EdumedHolguín 2019. Available in: http://edumedholguin2019.sld.cu/index.php/201 9/2019/paper/view/75/272

[4] AltirkawiK. Teaching professionalism in medicine: what, why and how? Sudan J Paediatr. 2014; 14(1): 31-38.Available in: https://www.ncbi.nlm.nih.gov/pmc/articles/PM C4949913/

[5] Byyny RL. Medical professionalism in the modern era. The Pharos, Winter 2018. Available in: http://alphaomegaalpha.org/ pharos/PDFs/2018/Winter/2018-1-Byyny.pdf

[6] PastroFiat SM. Saberes docentes en educación médica. Journal forEducators, Teachers and Trainers2015; 6(1):124 - 144.Available in: http://www.labosfor.com/jett/index.php/jett/arti cle/viewFile/164/217

[7] Campos Costa NMS. La formación pedagógica de profesores de medicina. Rev. Latino-Am. Enfermagem 2010;19(1): 1-7. Available in: http://www.scielo.br/pdf/rlae/v18n1/es_16.pdf

[8] Osornio Castillo L, Sánchez Reyes C, Ríos Saldaña MR, Méndez Cruz AR, Moreno Fernández AA, Ángeles Cruz RT, Hurtado Díaz JL. Autoevaluación de los profesores de clínica integral de medicina sobre su desempeño docente. RevInvest en EducMéd 2015;4(16): 183-189. Available in: 
Teaching Professionalization of the Current Need Physician

https://www.sciencedirect.com/science/article/p ii/S2007505715000265/pdfft?md5=bd4244eb1 a76794b6152e14e42323511\&pid=1-s2.0-S20 07505715000265-main.pdf

[9] Cuba, Ministerio de Educación Superior. Resolución Ministerial No. 85/2016 del 17 de octubre del 2016. Reglamento para la aplicación de las categorías docentes de la educación superior. Gac Of Repub Cuba. 2017;5. Available in:https://www.gacetaoficial. gob.cu/pdf/GOC-2017-O5.rar Acceso el 14 de diciembre del 2017.

Citation: Claribel Plain Pazos et.al, "Teaching Professionalization of the Current Need Physician", International Journal of Research Studies in Medical and Health Sciences. 2020; 5(6): 36-38.

Copyright: (C) 2020 Claribel Plain Pazos et.al, This is an open-access article distributed under the terms of the Creative Commons Attribution License, which permits unrestricted use, distribution, and reproduction in any medium, provided the original author and source are credited. 